\title{
Prevalence and Antibiogram Study of Escherichia coli and Staphylococcus aureus in Turkey Meat in Morocco
}

\section{El Allaoui Abdellah ${ }^{*}$, Rhazi Filali Fouzia ${ }^{1}$ and Oumokhtar Bouchra ${ }^{2}$}

${ }^{1}$ Team Microbiology and Health, Department of Biology, Laboratory of Applied Chemistry Biology Environment, Moulay Ismail University, Faculty of Science, BP11201 Zitoune Meknes, Morocco

${ }^{2}$ Laboratoire of Microbiology, Faculty of Medicine and Pharmacy of Fez, BP1893, Morocco

\begin{abstract}
This study presents a survey of the microbiological quality of turkey meat sold in various outlets in Meknes city of Morocco and examines antimicrobial resistance of Staphylococcus aureus and Escherichia coli strains isolated to warn customers about the emergence of food poisoning. 96 samples randomly taken on different outlets, including 24 at the popular market, 24 at artisanal slaughterhouses, 24 at poulterers' shops and 24 at supermarket. According to the microbiological criteria, $83.3 \%$ of samples did not meet the standards for E. coli. $95.8 \%, 33.3 \%, 41.6 \%, 41.6 \%$ of the samples purchased from supermarket, poulterers' shops, artisanal slaughterhouses and popular market outlets, respectively, showed satisfactory quality point of view S. aureus among which $8.3 \%(8 / 96)$ of samples could be linked to a foodborne due to a concentration of $S$. aureus upper in $5 \log _{10} \mathrm{vfc} / \mathrm{g}$. The level of contamination E. coli and $S$. aureus at supermarket was recorded significantly lower $(p<0.05)$ compared to other sites.
\end{abstract}

Among the $40 \mathrm{E}$. coli tested, the highest resistance was to amoxicillin-clavulanic acid ( $80 \%)$, followed by norfloxacin $(67.5 \%)$, cephalothin $(65 \%)$, nalidixic acid $(62.5 \%)$, ampicillin $(52 \%)$, trimethoprim/sulphamethoxazole $(42.5 \%)$, ciprofloxacin $(40 \%)$, cefoxitin (35\%), ceftazidime $(32.5 \%)$ and amikacin $(15 \%)$. Low resistance rates were returned (between 5 and $12.5 \%$ ) for ertapenem, aztreonam and gentamicin. For S. aureus, the highest percentage of resistance was found to the following antimicrobial agents: teicoplanin (67.5\%), tetracyclin (40\%) and vancomycin (30\%). No resistance to the rest of antibiotics was found.

The bacterial load present on the surface of poultry carcasses reflects the general hygiene conditions in which they are prepared, stored, transported and sold. These data revealed also that the $E$. coli and $S$. aureus isolates recovered from the retail turkey meats were resistant to multiple antimicrobials, which can be transmitted to humans through food products.

Keywords: Turkey meat; Microbiological quality; Morocco; Health; Antimicrobial resistance

\section{Introduction}

Food borne diseases and poisoning are the widespread and great public health concerns of the modern world. Both developed and developing countries are largely affected by food borne infections. Food borne diseases not only affect people's health and well-being, but also have economic impacts on individuals and the countries [1], while the impact in case of developing countries is higher. It reduces markedly social and economic productivity of the countries [2]. Because of the relatively high frequency of contamination of poultry with pathogenic bacteria, raw poultry products are reported to be responsible for significant number of cases of human food poisoning [3].

Poultry meat contributes substantially to the human diet [4]. In Morocco, poultry meat is an important, low cost source of animal protein. This encourages the consumption of poultry products by a large number of consumers. Poultry meat is increasingly used by the growing rural and urban populations. This explains the high production in Morocco especially that the turkey fell from 10.5 to 50 million tonnes in recent years [5]. However, foods of animal origin, especially poultry and meat, are the major vehicles for the transmission of human salmonellosis due to cross-contamination events or inadequate cooking [6]. In Morocco, although several efforts diseases have been made to improve food safety and quality, food borne diseases still represent one of the main causes of mortality [7].

Amongst the food borne pathogens, Salmonella and S. aureus are the most common and frequent pathogens responsible for food poisoning and food related infections [8,9]. According to WHO [10], there was $25 \%$ diarrhea in foodborne illness caused by food infected with E. coli. In Morocco, Salmonella, S. aureus and Clostridium perfringens are reported to cause $42.8,37$, and $1.7 \%$ of food poisoning, respectively [11].

Four kinds of turkey meat outlets are used in Morocco: popular market, artisanal slaughterhouses, poulterers' shops and supermarket. They differ from each other by the level of hygiene, diet cold which is subject carcasses (ambient temperatures, refrigeration, freezing). At popular market and artisanal slaughterhouses the conditions of slaughter and sale of the product are faulty [11], indeed turkey is slaughtered and scalded in hot water. After that, the carcasses are plucked and eviscerated mostly by hand. Before and after evisceration, broil carcasses are subject to washing and other operations which my disseminate bacteria from localized sites to the rest of the carcass as

*Corresponding author: El Allaoui Abdellah, Team Health and Microbiology, Department of Biology, Laboratory of Applied Chemistry Biology Environment, Moulay Ismail University, Faculty of Science, BP11201 Zitoune Meknes, Morocco, E-mail: alaouixsaraa@hotmail.com

Received August 30, 2013; Accepted September 29, 2013; Published October 03, 2013

Citation: Abdellah EA, Fouzia RF, Bouchra O (2013) Prevalence and Antibiogram Study of Escherichia coli and Staphylococcus aureus in Turkey Meat in Morocco. Pharmaceut Anal Acta 4: 270. doi: 10.4172/2153-2435.1000270

Copyright: (c) 2013 Abdellah EA, et al. This is an open-access article distributed under the terms of the Creative Commons Attribution License, which permits unrestricted use, distribution, and reproduction in any medium, provided the original author and source are credited. 
well as among carcasses. This kind of poultry is often sold in parts and the selling can take time, during which the carcasses are displayed at ambient temperatures during the day and put in the refrigerator for the night $[12,13]$. In these shops, the conditions are favorable to potential contamination by pathogens which may originate from the animal itself and environment factors (water, litter, air). On the contrary, poulterers' shops and supermarket are an automated poultry slaughtering process established recently, whereby automated systems are used for scalding, plucking, eviscerating and packaging carcasses. Carcasses are then stored at $4^{\circ} \mathrm{C}$ before sale to supermarkets and Poulterers' shops. These shops ensure the storage and sale of poultry meat under good hygienic conditions [14].

Besides, Morocco is a developing country with abuse of antibiotics in animal husbandry and it may cause antimicrobial resistance of bacteria animals. Schroeder et al. [15] proved that antibiotic resistance of bacteria isolated from humans was transferred from antibiotic resistant bacteria in animal.

The purpose of this study is to detect the contamination bacteria of retail turkey meat in retail markets in Meknes (Morocco) and examined antimicrobial resistance of $S$. aureus and E. coli strains isolated to warn customers about the emergence of food poisoning.

\section{Material and Methods}

\section{Samples}

Between October 2011 and October 2012, a total of Ninety-six samples of turkey breasts with skin were collected from retailers, of which 24 samples were from popular market, 24 from artisanal slaughterhouses, 24 from poulterers' shops and 24 from a supermarket in Meknes (centre-south Morocco). Each sample was placed in a separate sterile plastic bag. Samples were transported to the laboratory immediately after collection in an ice chest and tested upon arrival or stored at $2^{\circ} \mathrm{C}$ for no longer than $4 \mathrm{~h}$.

\section{Statistical analysis}

All bacterial counts were expressed as $\log _{10}$ colony forming unit per $g\left(\log _{10} \mathrm{CFU} / \mathrm{g}\right)$. To compare the $\log _{10}$ values of microbial counts, the data were analyzed using Student's $t$ test for each type of microorganism. Significance was determined at the $5 \%$ level.

\section{Microbiological analysis}

A $25 \mathrm{~g}$ sample of skin was taken aseptically by scalpel excision and stomached in a sterile stomacher bag containing $225 \mathrm{ml}$ of peptone water (Biokar Diagnostics, France) for $2 \mathrm{~min}$. Decimal dilutions were carried out using the same diluents.

Mesophiles were determined using plate count agar (Oxoid, England) spread plates incubated at $30^{\circ} \mathrm{C}$ for 72 h. S. aureus on BairdParker agar with egg yolk-potassium tellurite emulsion plates (Bio$\mathrm{Rad}$ ), incubated at $35 \pm 1^{\circ} \mathrm{C}$ for 24 to $48 \mathrm{~h}$ and typical colonies (black surrounded by clear zones) were tested for coagulase activity using rabbit plasma (Biokar Diagnostics, France) after activation by overnight incubation in Brain Heart broth (Biokar Diagnostics, France) at $35^{\circ} \mathrm{C}$. E. coli counts, on rapid' E. coli Agar (Bio-Rad, France) incubated at $37^{\circ} \mathrm{C}$ for 18 to $24 \mathrm{~h}$, typical E. coli were considered as violet-to-pink.

\section{Susceptibility to antimicrobials}

Antibiotic susceptibility testing was performed by a disc diffusion method on Mueller-Hinton agar. The categories susceptible or resistant were assigned on the basis of the critical points recommended by the French committee on guidelines for susceptibility testing [16].The strains were screened for their resistance to the following antibiotics (Marnes-La-Coquette, France): nalidixic acid Na $30 \mu \mathrm{g}$; ciprofloxacin CIP $5 \mu \mathrm{g}$; ceftazidime CAZ $30 \mu \mathrm{g}$; amoxicillin-clavulanic acid AMC $20+10 \mu \mathrm{g}$; cefoxitin FOX $30 \mu \mathrm{g}$; cefotaxime CTX $30 \mu \mathrm{g}$; lincomycin, MY $15 \mu \mathrm{g}$; fusidic acid FD $10 \mu \mathrm{g}$; tetracycline TE $30 \mathrm{UI}$; teicoplanin TEC $30 \mu \mathrm{g}$; gentamycin CN $15 \mu \mathrm{g}$; vancomycin VA $30 \mu \mathrm{g}$; Rifampycin RD $30 \mu \mathrm{g}$; amikacin AK $30 \mu \mathrm{g}$; ertapenem ETP $10 \mu \mathrm{g}$; cephalothin KF $30 \mu \mathrm{g}$; aztreonam ATM $30 \mu \mathrm{g}$; ampicillin AM $10 \mu \mathrm{g}$; trimethoprim/ sulphamethoxazole SXT 1.25/23.75 $\mu \mathrm{g}$ and norfloxacin NOR $5 \mu \mathrm{g}$. We used the Automated System (OSIRIS) for reading and interpreting results (Bio-Rad).

\section{Results and Discussion}

\section{Mesophiles}

It is important to determine the aerobic total criterion which is used as hygienic indicator in the slaughter- process. In total of 96 samples, the number of bacteria was $4.15 \log _{10} \mathrm{CFU} / \mathrm{g}$ in minimum registered in samples from the supermarket and in maximum $8.66 \log _{10} \mathrm{CFU} / \mathrm{g}$ registered in samples from slaughterhouses (Table 1). From this point of view parameter (mesophiles), the percentage of unacceptable samples was $48.95 \%$ (Table 1). This result was higher than the result obtained by Cohen et al. [17] in Morocco with 29.2\% unacceptable samples of poultry meat poultry. In Hanoi, Nguyen Van Ton [18] found 54.65\% meat poultry samples over national standards (Figure 1a).

\begin{tabular}{|c|c|c|c|c|c|c|}
\hline \multirow{2}{*}{} & \multicolumn{2}{|c|}{ Mesophiles } & \multicolumn{2}{c|}{ E. coli } & \multicolumn{2}{c|}{ S. aureus } \\
\cline { 2 - 8 } & Min-Max & A & Min-Max & A & Min-Max & A \\
\hline Samples from & $\log _{10}$ ufc/g & N\% & $\log _{10}$ ufc/g & N\% & $\log _{10}$ ufc/g & N\% \\
\hline slaughterhouses & $6.05-8.66$ & $10 / 24$ & $1.8-4.88$ & $5 / 24$ & $2.62-5.65$ & $10 / 24$ \\
\hline Poulterers' shops & $5.69-7.81$ & $9 / 24$ & $2.02-5.49$ & $2 / 24$ & $2.30-5.70$ & $8 / 24$ \\
\hline Super market & $4.15-7.60$ & $19 / 24$ & $2.65-4.78$ & $5 / 24$ & $0-4.48$ & $23 / 24$ \\
\hline Popular market & $4.88-8.26$ & $15 / 24$ & $1.67-4.96$ & $4 / 24$ & $2.3-5$ & $10 / 24$ \\
\hline Range* & \multicolumn{2}{|c|}{$<6.7 \log _{10}$ ufc/g } & $<2.2 \log _{10}$ ufc/g & $<3.7 \log _{10}$ ufc/g \\
\hline
\end{tabular}

A: Acceptable, N\%: Rate of compliance, Min: Minimum, Max: Maximum, Range*: According to the microbiological criteria for raw meat poultry [37].

Table 1: Bacterial counts $\left(\log _{10} \mathrm{cfu} / \mathrm{g}\right)$ found in retail turkey outlets $(n=96)$.

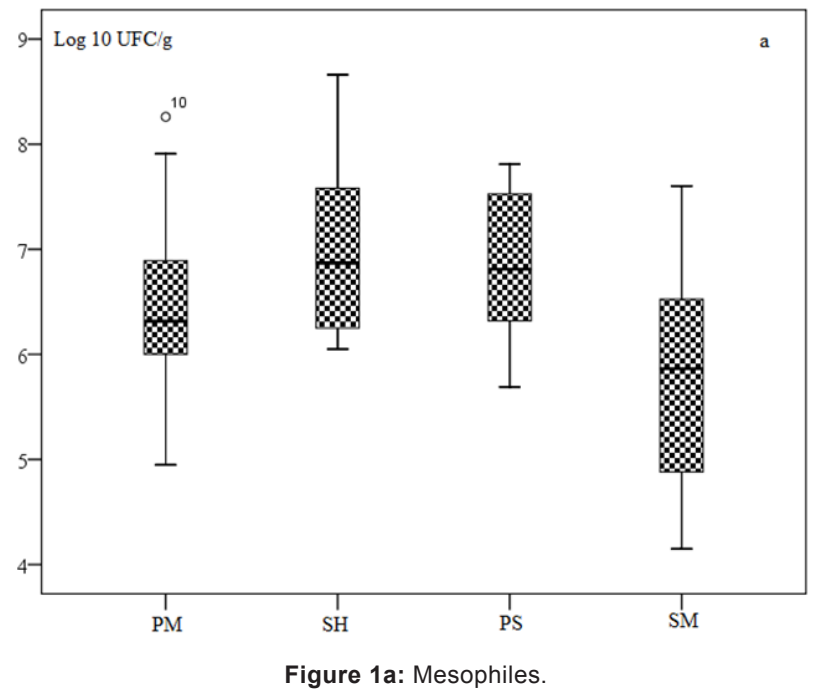




\section{Escherichia coli}

Coli form bacteria are indicator organisms as enterobacteriaceae are of intestinal origin. Indicator organisms may be employed to reflect the microbiological quality of foods relative to product shelf life or their safety from food borne pathogens. Microbial indicators are more often employed to assess food safety and sanitation than quality $[19,20]$. According to WHO [10], there was $25 \%$ diarrhea in food borne illness caused by food infected with E. coli. In this study, for these bacteria, average counts were $3.43 \log _{10} \mathrm{CFU} / \mathrm{g}$ in samples purchased from super market and $3.85 \log _{10} \mathrm{CFU} / \mathrm{g}$ in those purchased from artisanal slaughterhouses (Figure 1c). In this study $100 \%$ of food samples were infected with E. coli. There was $5.49 \log _{10} \mathrm{CFU} / \mathrm{g}$ in maximum and $1.67 \log _{10}$ CFU/g in minimum (Table 1). Proportion of unacceptable sample was $83.3 \%$ (Table 1), higher than some results announced. Tran Thi Hanh et al [21] found $68.75 \%$ samples of poultry meat sold in Hanoi's market. In America, 38.7\% meat poultry samples in Washington infected with E. coli (Cuiwei Zhao et al.) [22]. Cohen $\mathrm{N}$ et al. [17] indicated 48.4\% samples infected with E.coli in Morocco, 22.4\%

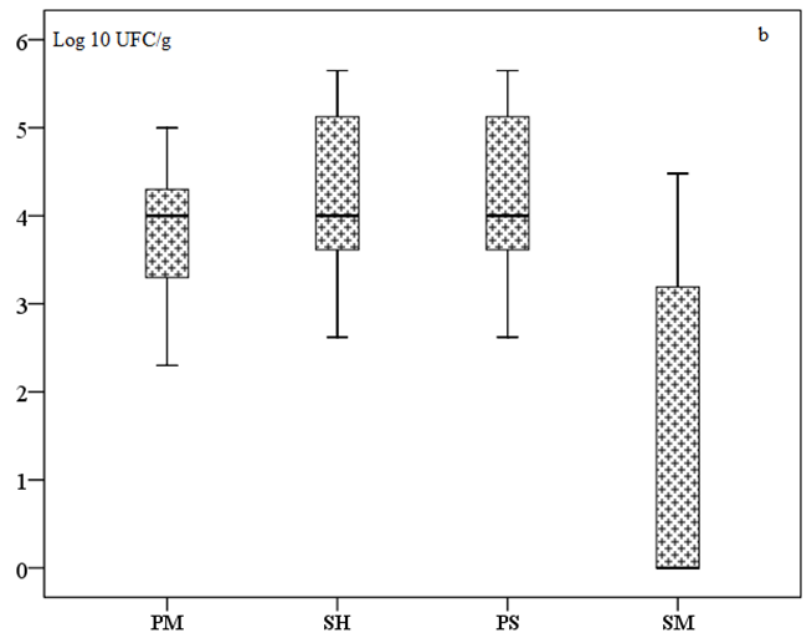

Figure 1b: Staphylococcus aureus.

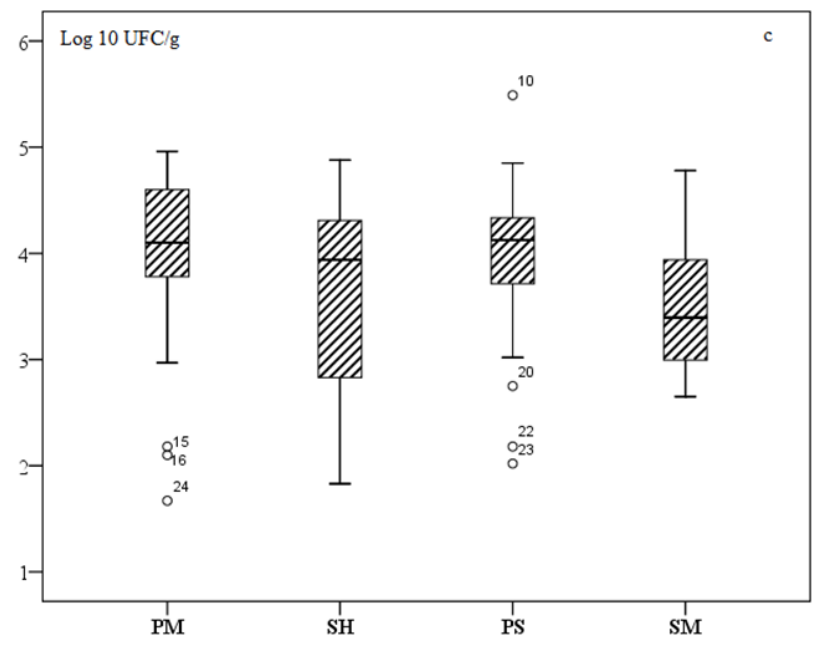

PM: Popular market; SH: Artisanal slaughterhouses; PS: Poulterers' shops; SM: Supermarket; (On): Samples "n" to extreme values not included in the curve box mustache.

Figure 1c: Escherichia coli. among these was unacceptable. Levels of contamination of samples were significantly $(\mathrm{P}<0.05)$ higher in poulterers' shops, slaughterhouses and in popular market than in supermarkets, possibly due to the good hygienic conditions in the supermarkets at the time of the previous stages (Figure 1c).

\section{Staphylococcus aureus}

S. aureus has long been recognized as one of the food poisoning bacteria of concern to human health worldwide [23]. Average counts of $S$. aureus in samples purchased from popular market and artisanal slaughterhouses outlets were 3.85 and $4.19 \log _{10}$ CFU/g respectively (Figure 1b). These levels of contamination were higher to those obtained by Âlvarez-Astorga et al. [24] in chicken legs. Similarly, Waldroup AL [25] obtained values ranging from 3 to $5 \log _{10} \mathrm{CFU} / \mathrm{g}$. Counts found by other authors are very variable. However, in samples purchased from supermarket, S. aureus counts were lower than those of other outlets. On the basis of the CNERNA-CNRS guidelines [26], 95.8\%, 33.3\%, 41.6\%, $41.6 \%$ of the samples purchased from supermarket, poulterers' shops, artisanal slaughterhouses and popular market outlets, respectively, showed satisfactory quality. The rest of the samples were considered of the unacceptable quality (Table 1). Enumeration of $S$. aureus revealed that the count of pathogen exceeded $5 \log _{10} \mathrm{CFU} / \mathrm{g}$ in 8 out of the 96 analysed samples (8.3\%). Such high level of contaminated with $S$. aureus has been associated with increased risk for staphylococcal food poisoning [27]. High contamination of food with S. aureus has been related to improper personal hygiene of employees during handling and processing [28].

This comparison should be made with caution because several factors must be taken into account when making such comparisons, including differences in country and origin, type of meat samples, sampling seasons, slaughterhouse sanitation, and isolation methods.

\section{Antibioresistance}

Food is an important factor for the transfer of antibiotic resistances. Such transfer can occur by means of antibiotic residues in food, through the transfer of resistant food-borne pathogens or through the ingestion of resistant strains of the original food microflora and resistance transfer to pathogenic microorganisms $[29,30]$. S. aureus strains are known to be frequently resistant to antibiotic therapy due to their capacity to produce an exopolysaccharide barrier and because of their location within micro abscesses, which limit the action of drugs [31].

Antibiotic resistance in $S$. aureus strains to 8 antimicrobial agents is shown in Table 2. Overall, the highest percentage of resistance was found to the following antimicrobial agents: teicoplanin (67.5\%), tetracyclin (40\%) and vancomycin (30\%). No resistance to the rest of antibiotics was found. Otalu et al. [32] reported 100\% resistance in S. aureus isolates from poultry meat against tetracycline and $61.5 \%$ against methicillin in Nigeria [32]. Multidrug resistant $S$. aureus have been reported several times [33]. Extensive uses of these antibiotics are thought to be the major cause of drug resistance in food borne pathogens [32].

Antibiotic resistance in E. coli strains to 14 antimicrobial agents is shown in Table 3. Overall, the highest percentage of resistance was found to the following antimicrobial agents: amoxicillin-clavulanic acid (80\%), norfloxacin (67.5\%), cephalothin (65\%), nalidixic acid (62.5\%), ampicillin (52\%), trimethoprim/sulphamethoxazole (42.5\%), ciprofloxacin (40\%), cefoxitin (35\%), ceftazidime (32.5\%) and amikacin (15\%). Low resistance rates were returned (between 5 and 12.5\%) for ertapenem, aztreonam and gentamycin. In Morocco, Chaiba et al. 
Citation: Abdellah EA, Fouzia RF, Bouchra O (2013) Prevalence and Antibiogram Study of Escherichia coli and Staphylococcus aureus in Turkey Meat in Morocco. Pharmaceut Anal Acta 4: 270. doi: 10.4172/2153-2435.1000270

Page 4 of 5

\begin{tabular}{|c|c|c|c|c|c|c|c|}
\hline \multirow{2}{*}{ Antibiotic } & \multirow{2}{*}{$\begin{array}{c}\text { Concentration } \\
\text { Disc }\end{array}$} & \multicolumn{3}{|c|}{ S (Sensitive) } & \multicolumn{3}{|c|}{ R (Resistant) } \\
\hline & & diameter $(\mathrm{mm})$ & $\mathrm{n}$ & $\%$ & diameter $(\mathrm{mm})$ & $\mathbf{n}$ & $\%$ \\
\hline FOX & $30 \mu \mathrm{g}$ & $\geq 27$ & 40 & 100 & $<25$ & 0 & 0 \\
\hline MY & $15 \mu \mathrm{g}$ & $\geq 22$ & 40 & 100 & $<17$ & 0 & 0 \\
\hline FD & $10 \mu \mathrm{g}$ & $\geq 24$ & 40 & 100 & $<24$ & 0 & 0 \\
\hline TE & $30 \mathrm{UI}$ & $\geq 23$ & 24 & 60 & $<21$ & 16 & 40 \\
\hline TEC & $30 \mu \mathrm{g}$ & $\geq 17$ & 13 & 32.5 & - & 27 & 67.5 \\
\hline $\mathrm{CN}$ & $15 \mu g$ & $\geq 20$ & 40 & 100 & $<13$ & 0 & 0 \\
\hline VA & $30 \mu \mathrm{g}$ & $\geq 17$ & 28 & 70 & - & 12 & 30 \\
\hline $\mathrm{RD}$ & $30 \mu \mathrm{g}$ & $\geq 29$ & 40 & 100 & $<24$ & 0 & 0 \\
\hline
\end{tabular}

Total 40 S. aureus strains were examinated.

Table 2: Result of antibiotic resistance of $S$. aureus isolated.

\begin{tabular}{|c|c|c|c|c|c|c|c|}
\hline \multirow{2}{*}{ Antibiotic } & \multirow{2}{*}{$\begin{array}{c}\text { Concentration } \\
\text { Disc }\end{array}$} & \multicolumn{3}{|c|}{ S (Sensitive) } & \multicolumn{3}{|c|}{ R (Resistant) } \\
\hline & & diameter (mm) & $\mathbf{n}$ & $\%$ & diameter (mm) & $\mathbf{n}$ & $\%$ \\
\hline NA & $30 \mu \mathrm{g}$ & $\geq 20$ & 15 & 37,5 & $<15$ & 25 & 62,5 \\
\hline $\mathrm{CN}$ & $15 \mu \mathrm{g}$ & $\geq 18$ & 38 & 95 & $<16$ & 2 & 5 \\
\hline CIP & $5 \mu \mathrm{g}$ & $\geq 25$ & 24 & 60 & $<22$ & 16 & 40 \\
\hline AK & $30 \mu \mathrm{g}$ & $\geq 17$ & 34 & 85 & $<15$ & 6 & 15 \\
\hline FOX & $30 \mu \mathrm{g}$ & $\geq 22$ & 26 & 65 & $<15$ & 14 & 35 \\
\hline ETP & $10 \mu \mathrm{g}$ & $\geq 28$ & 35 & 87,5 & $<26$ & 5 & 12,5 \\
\hline CTX & $30 \mu \mathrm{g}$ & $\geq 26$ & 40 & 100 & $<23$ & 0 & 0 \\
\hline CAZ & $30 \mu \mathrm{g}$ & $\geq 26$ & 17 & 42,5 & $<19$ & 13 & 32,5 \\
\hline KF & $30 \mu \mathrm{g}$ & $\geq 18$ & 14 & 35 & $<12$ & 26 & 65 \\
\hline AMC & $20 / 10 \mu \mathrm{g}$ & $\geq 21$ & 8 & 20 & $<16$ & 32 & 80 \\
\hline ATM & $30 \mu \mathrm{g}$ & $\geq 27$ & 32 & 80 & $<21$ & 2 & 5 \\
\hline AM & $10 \mu \mathrm{g}$ & $\geq 19$ & 19 & 47,5 & $<16$ & 21 & 52,5 \\
\hline SXT & $1.25 / 23.75 \mu \mathrm{g}$ & $\geq 16$ & 23 & 57,5 & $<13$ & 17 & 42,5 \\
\hline NOR & $5 \mu \mathrm{g}$ & $\geq 25$ & 13 & 32,5 & $<22$ & 27 & 67,5 \\
\hline
\end{tabular}

Total 40 E. coli strains were examinated.

Table 3: Result of antibiotic resistance of $E$. coli isolated.

[34] obtained resistance in E. coli strains of poultry meat to tetracyclin (80\%), chloramphenicol (6.6\%), amoxiline $(20 \%)$, acid nalidixic (26.6\%), gentamycin (0\%), Neomycin (6.6\%) and trimethoprim/ sulphamethoxazole (33.33\%). Antunes et al. [35] also reported a high antimicrobial resistance of Salmonella isolates recovered from poultry products including chicken and turkey to nalidixic acid, tetracycline and streptomycin (ranging from $36 \%$ to $50 \%$ ) but low resistance rate to trimethoprim (3\%) in Portugal. We noticed also an increase of resistance to ciprofloxacin (40\%), that represent the treatment of choice of severe non typhoidal Salmonella infection in adults [36,37]. This could be related to the use of some fluoroquinolones form methaphylactic or therapeutic purposes in poultry feed and drinking water.

\section{Conclusion}

The results of this study indicate the lack of unsatisfactory sanitary conditions and quality control during manufacturing and/or post production handling of the turkey meats, and a possible health safety problem. Also, the results clearly indicate that attempts have to improve the sanitary conditions in traditional turkey meat production procedure and we recommend more restrictions on the irrational use of antibiotics and public awareness activities should be undertaken to alert the public to the risks of the unnecessary use of antibiotics.

\section{References}

1. Carbas B, Cardoso L, Coelho AC (2012) Investigation on the knowledge associated with foodborne diseases in consumers of northeastern Portugal. Food Control 30: 54-57.

2. Pires SM, Vieira AR, Perez E, Lo Fo Wong D, Hald T (2012) Attributing human foodborne illness to food sources and water in Latin America and the Caribbean using data from outbreak investigations. Int J Food Microbiol 152: 129-138.

3. Geornaras I, de Jesus A, van Zyl E, von Holy A (1995) Microbiological survey of a South African poultry processing plant. J Basic Microbiol 35: 73-82.

4. Capita RCA, Calleja M, Pieetro M, Fernandez M, Del CG , Moreno B (2002) Incidence and pathogenicity of Yersinia spp. isolates from poultry in Spain. Food Microbiol 19: 295-301.

5. Anonymous (2008) Fisa. Documentations \& statistiques.

6. Capita R, Alonso-Calleja C, Prieto M (2007) Prevalence of Salmonella enterica serovars and genovars from chicken carcasses in slaughterhouses in Spain. $J$ Appl Microbiol 103: 1366-1375.

7. Karib H (2001) A propos des toxi-infections alimentaires collectives. Animalis 2: 44-51.

8. Costa LF, Paixão TA, Tsolis RM, Bäumler AJ, Santos RL (2012) Salmonellosis in cattle: advantages of being an experimental model. Res Vet Sci 93: 1-6.

9. Aydin A, Sudagidan M, Muratoglu K (2011) Prevalence of staphylococcal enterotoxins, toxin genes and genetic-relatedness of foodborne Staphylococcus aureus strains isolated in the Marmara Region of Turkey. Int J Food Microbiol 148: 99-106.

10. WHO (2006) WHO Global Slam Surv Progess Report 2000 - 2005.

11. Department of epidemiology (2005) Foodborne Disease Outbreak Reports, Searchable Data 2000-2005. Ministry of Public Health, Rabat, Morocco.

12. Amara A, Badoum M, Faid M, Bouzoubaa K (1994) Microbial contamination of poultry slaughtered in traditional shops in Morocco. Microbiol Aliment Nutr 12: 323-327.

13. Aymar J (1998) Appréciation de la qualité bactériologique des carcasses de la volaille préparées dans un abattoir avicole industriel à Rabat, Thèse de Doctorat Vétérinaire, Institut Agronomique et Vétérinaire Hassan II, Rabat. 
Citation: Abdellah EA, Fouzia RF, Bouchra O (2013) Prevalence and Antibiogram Study of Escherichia coli and Staphylococcus aureus in Turkey Meat in Morocco. Pharmaceut Anal Acta 4: 270. doi: 10.4172/2153-2435.1000270

Page 5 of 5

14. Direction de l'élevage (2007) Situation du secteur avicole à la veille de l'application de la loi 49/99. Rabat, Maroc.

15. Schroeder CM, Zhao C, DebRoy C, Torcolini J, Zhao S, et al. (2002) Antimicrobial resistance of Escherichia coli 0157 isolated from humans, cattle, swine, and food. Appl Environ Microbiol 68: 576-581.

16. Comité de l'Antibiogramme de la Société Française de Microbiologie (C.A.S.F.M.) Communiqué 2010. Edition 2010.

17. Cohen N, Ennaji H, Bouchrif B, Hassar M, Karib H (2007) Comparative Study of Microbiological Quality of Raw Poultry Meat at Various Seasons and for Different Slaughtering Processes in Casablanca (Morocco) The Journal of Applied Poultry Research 16: 50-508.

18. Nguyen Van Ton (2005) Research on the situation of poultry slaughter houses, some veterinarian criteria in chicken in urban of Hanoi and response. Thesis of Master Degree, Hanoi University of Agriculture.

19. Buttiaux R, Mossels DAA (1961) The Significance of Various Organisms of Faecal Origin in Foods and Drinking Water. J Appl Bacteriol 24: 353-364.

20. Tompkin RB (1983) Indicator organisms in meat and poultry products. Food Technol 37:107-110.

21. Tran Thi H, Luu Quynh H (2004) The situation of E. coli and Salmonella contamination in animal products in Hanoi and the results of microbia identification. Science Report. Conference Veterinary - Livestock Husbandry.

22. Zha C, Ge B, De Villene J, Sudler R, Yeh E, et al. (2001) Prevalence of Campylobacter spp., Escherichia coli, and Salmonella Serovars in Retail Chicken, Turkey, Pork, and Beef from the Greater Washington, D.C., Area. Applied and Environmental Microbiology, 67: 5431-5436.

23. Acco M, Ferreire FS, Henrique JAP, Tondo EC (2003) Identification of multiple strains of Staphylococcus aureus colonizing nasal mucosa of food handlers . Food Microbiol 20: 489-493.

24. Alvarez-Astorga M, Capita R, Alonso-Calleja C, Moreno B, Del M, et al. (2002) Microbiological quality of retail chicken by-products in Spain. Meat Sci 62: 45-50.

25. Waldroup AL (1996) Contamination of raw poultry with pathogens. World Poult Sci J 52: 7-25.

26. CNERNA-CNRS (1996) (Centre Nationale d'Etudes et de recommendations sur la Nutrition et l'Alimentation) Critères microbiologiques. In: La qualité microbiologique des aliments (Jouve,J.L.ed.) Polytechnica Paris 353-361.

27. Peiffer B (1999) Toxi-infections alimentaires à Staphylocoques. Actualité TIAC France.

28. Hatakka M, Björkroth KJ, Asplund K, Mäki-Petäys N, Korkeala HJ (2000) Genotypes and enterotoxicity of Staphylococcus aureus isolated from the hands and nasal cavities of flight-catering employees. J Food Prot 63: 1487-1491.

29. Khan SA, Nawaz MS, Khan AA, Cerniglia CE (2000) Transfer of erythromycin resistance from poultry to human clinical strains of Staphylococcus aureus. J Clin Microbiol 38: 1832-1838.

30. Pesavento G, Ducci B, Comodo N, Nostro AL (2007) Antimicrobial resistance profile of Staphylococcus aureus isolated from raw meat: A research for methicillin resistant Staphylococcus aureus (MRSA) Food Control 18: 196-200.

31. Gundocan N, Citak S, Turan E (2006) Slime production, DNase activity and antibiotic resistance of Staphylococcus aureus isolated from raw milk, pasteurized milk and ice cream samples. Food Control 17: 389-392.

32. Otalu OJ, Junaidu K, Chukwudi OE, Jarlath UV (2011) Multi-Drug Resistan Coagulase Positive Staphylococcus aureus from Live and Slaughtered Chickens in Zaria, Nigeria. Int J Poul Sci 10: 871-875.

33. Waters AE, Contente-Cuomo T, Buchhagen J, Liu CM, Watson L, et al. (2011) Multidrug-Resistant Staphylococcus aureus in US Meat and Poultry. Clin Infect Dis 52: 1227-1230.

34. Chaiba A (2011) Impact des pratiques de production de poulet de chair à Meknès sur la qualité bactériologique, l'antibiorésistances et les résidus d'antibiotiques dans les produits aviaires finis, Thèse de Doctorat National, Université Moulay Ismail, Faculté des Sciences de Meknès, Maroc.

35. Antunes P, Réu C, Sousa JC, Peixe L, Pestana N (2003) Incidence of Salmonella from poultry products and their susceptibility to antimicrobial agents. Int J Food Microbiol 82: 97-103.

36. Bouchrif B, Karraouan B, Ennaji MM, Timinouni M (2008) Quinolones-resistant Salmonella spp. in Casablanca - Morocco. Med Mal Infect 38: 615-616.

37. Ministère de l'Agriculture (2004) Département de la production Animale Rabat. Les normes microbiologiques auxquelles doivent répondre les denrées alimentaires d'origine alimentaire. $\mathrm{N}^{\circ}$ 624-04.Off Bull 5214: 727-745. 